\title{
Proliferation and cell death in an experimental model of brain tissue heterotopia in the lung ${ }^{1}$
}

\author{
Proliferação e morte celular na heterotopia encefálica experimental
}

\author{
Paulo Roberto Veiga Quemelo ${ }^{\mathrm{I}}$ Luiz Cesar Peres ${ }^{\mathrm{II}}$ \\ ${ }^{\mathrm{I}} \mathrm{MD}$, Department of Physiotherapy, University of Franca, São Paulo, Brazil. \\ ${ }^{\text {II }} \mathrm{PhD}$, Professor of Department of Histopathology, Sheffield Children's NHS, Foundation Trust, University of Sheffield, Sheffield, United King.
}

\begin{abstract}
Purpose: To investigate the proliferation and neuronal death in brain tissue heterotopia in the lung in an experimental model during both fetal and neonatal periods. Methods: Twenty four pregnant female Swiss mice were used to induce brain tissue heterotopia on the 15 th gestational day. Briefly, the brain of one fetus of each dam was extracted, disaggregated and injected into the right hemithorax of siblings. Six of these fetuses with pulmonary brain tissue implantation (PBI) were collected on the 18th gestational day (group E18) and six other on the 8th postnatal day (group P8). Immunohistochemical staining for PCNA and Bcl2 were used to assess proliferation and cell death. Results: PCNA Labelling Index (LI) in heterotopic brain tissue was greater in fetal than postnatal period (E18 $>$ P8) $(\mathrm{p}<0.05)$ and the immunostaining with $\mathrm{Bcl} 2$ antibody did not show difference. Conclusion: Cell proliferation is maintained in brain tissue heterotopia, although apoptosis is also observed.
\end{abstract}

Key words: Cell Proliferation. Cell Death. Mice.

\section{RESUMO}

Objetivo: Investigar a proliferação e morte neuronal na heterotopia encefálica pulmonar em modelo experimental durante o período fetal e neonatal. Métodos: Foram utilizados 24 camundongos Swiss fêmeas prenhes para induzir a heterotopia encefálica no pulmão. O tecido encefálico de um feto de cada fêmea prenha foi removido, picotado e injetado no pulmão dos irmãos. Seis fetos com Implantação Encefálica Pulmonar (IEP) foram coletados no $18^{\circ}$ dia gestacional (grupo E18) e seis outros fetos no $8^{\circ}$ dia pós-natal (grupo P8). Foi realizada a reação Imuno-histoquímica para PCNA e Bcl2 para analisar a proliferação e morte celular. Resultados: O índice de marcação (IM) para PCNA era maior no período fetal quando comparado com o período pós-natal $(E 8>P 18)(p<0,05)$ e a imunomarcação para o anticorpo Bcl2 não apresentou diferença. Conclusão: A proliferação celular foi mantida no tecido heterotópico encefálico, embora a apoptose também foi observada.

Descritores: Proliferação de Células. Morte Celular. Camundongos.

${ }^{1}$ Research performed at Department of Pathology, Faculty of Medicine, University of São Paulo, Ribeirão Preto (FMRP-USP), São Paulo, Brazil.

\section{Introduction}

The central nervous system (CNS) of vertebrates originates from neuroepithelial cells located within the embryonic neural tube ${ }^{1}$. Cell proliferation and death during development of the CNS comprise a complex process ${ }^{2}$ involving interplay between intrinsic cellular programs and extrinsic cues such as growth factors $^{3,4}$ and in order to adjust the size of the input population, some neurons with erroneous or inadequate projections are eliminated $^{5-7}$.

Thus, the adequate balance between proliferation and cell death is crucial for development of the CNS. However, little is known about these processes outside the CNS, such as in brain tissue heterotopia in the lung, a rare abnormality occasionally observed in malformed babies and fetuses ${ }^{8,9}$. The implantation

and growth of the brain tissue in the lung and the proliferative ability of these cells are not fully understood ${ }^{10,11}$.

It was recently developed an experimental model of heterotopic brain tissue in the lung ${ }^{12}$, which allows deeper investigation of the mechanisms involved in this abnormality.

Our previous study on the expression of NeuN using this model showed that neuronal maturation continued in the heterotopic brain tissue during fetal and neonatal periods in the same way as in the brain of controls, although with a reduction in the number of neurons in the experimental group ${ }^{13}$. Thus, the main goal of the present study was to investigate the cell proliferation and death in heterotopic brain tissue in the lung during fetal and neonatal period using immunohistochemical (IH) methodology. 


\section{Methods}

The experiment was approved by the Ethics Committee for Animal Experimentational (CETEA) (process \#018/2005).

Twenty-four pregnant female Swiss mice were obtained from the colony of the Central Animal House of Ribeirão Preto Campus of the University of São Paulo. The animals received water and appropriate commercial mouse chow ad libitum. The facility in which the animals were housed throughout the experiment is equipped with sound protection, is rigorously controlled with light/dark cycles of 12 hours each, has low luminosity, a constant temperature of $22^{\circ} \mathrm{C}$ and has an exhaust system for several changes of air along the day.

Surgery was performed in the morning of the 15 th gestational day (GD) under aseptic conditions, according to the method proposed by Quemelo et al. ${ }^{12}$. Briefly, pregnant dams were anesthetized with ketamine (Ketamina ${ }^{\circledR}$ - Pfizer do Brasil Ltda, São Paulo, Brazil) and xylazine (Rompum ${ }^{\circledR}$ - Bayer do Brasil Ltda, São Paulo, Brazil). Median laparotomy was done until exposure of the uterine horns. One fetus was removed by hysterotomy, its brain was removed, minced, disaggregated in RPMI culture medium (Medium 1640 with L-glutamine and without sodium bicarbonate; GibcoBRL, Grand Island, NY, USA) and introduced into the thorax of three siblings, denoted pulmonary brain tissue implantation (PBI).

Six fetuses with PBI were colleted from different dams on the 18th GD (group E18) and six others on the 8th postnatal day (group P8). PBI fetuses collected by cesarean section during gestational period were identified by its known position in the uterus whereas those from postnatal day 8 were identified after histological analysis of all liveborn fetuses. Six fetuses of control dams not submitted to any surgical procedures were collected on the 18th GD (group CE18) and on the 8th postnatal day (CP8) and their brains were used as control for the neuronal proliferation and apoptosis.

Immediately after collection, the trunks of PBI fetuses and the heads of control ones were fixed in buffered formalin. The proliferation and apoptosis were evaluated by IH using monoclonal antibody anti-PCNA (Novocastra, Newcastle upon Tyne, UK $1: 250$ ) and monoclonal antibody anti-Bcl-2 (Upstate, Temecula, CA, USA - 1:300). Antigen retrieval for GFAP, NeuN and PCNA was performed in a steamer with citrate buffer $\mathrm{pH} 6.0$ for 40 minutes, whereas antigen retrieval for $\mathrm{Bcl} 2$ was performed in a steamer with Tris-EDTA buffer $\mathrm{pH} 9.5$ for 40 minutes. The IH for antibodies GFAP and PCNA were done with immunoperoxidase method using the avidin-biotin complex (ABC). Secondary antibody (biotinylated, affinity-purified anti-immunoglobulin; Novocastra, Newcastle upon Tyne, UK) was incubated 30 minutes and then further incubated with $\mathrm{ABC}$ universal kit (Novostain Super ABC Kit, universal, Novocastra Laboratories, U.K.) also for 30 minutes. IH for $\mathrm{NeuN}$ and $\mathrm{Bcl}-2$ was performed with SuperPicTure Polymer Detection Kit (Zymed $^{\circledR}$ Laboratories Invitrogen, San Francisco, CA, USA) for 30 minutes. The DAB substrate was used for the development of the IH reaction (DAB; D5638, Sigma, St. Louis, MO, USA).

Only cells with strong nuclear staining with PCNA antibody were considered positive and were counted using a $40 \mathrm{X}$ objective lens, whereas for Bcl2 positive cells showed cytoplasmic and membrane staining. The labeling index (LI) was obtained by dividing the number of positive cells by the sum of positive and negative ones. All cells of heterotopic brain tissue from groups E18 and P8 were counted and compared to the mean PCNA and $\mathrm{Bcl} 2$ count from six areas chosen at random from subventricular (SVZ) and cortical brain regions from groups CE18 and CP8.

Data were analyzed statistically by Mann Whitney test using the GraphPad Prism 4.00 software (Prism, CA, USA), with the level of significance set at $\mathrm{p}<0.05$.

\section{Results}

Only $15(62.5 \%)$ of the 24 females initially assigned to the experiment could be used. Five died of anesthetic complications and four aborted.

PCNA LI was greater in heterotopic brain tissue in E18 group when compared to P8 $(\mathrm{p}<0.05)$ as show in Figure 1. PCNA LI in E18 was also greater than in group CE18 for cortical region and the mean of the cortical and $\mathrm{SVZ}(\mathrm{p}>0.05)$, but there was no difference for isolated SVZ region. PCNA LI was greater in heterotopic brain tissue in P8 group when compared to cortical region of the control group $(\mathrm{CP} 8)(\mathrm{P}<0.05)$.

PCNA LI was greater in SVZ than in cortical region in both controls groups (CE18 and CP8) $(\mathrm{P}>0.05)$. Additionally, CE18 PCNA LI of both SVZ and cortical region was greater than in respective areas in CP18 group (Table 1).

Positivity for $\mathrm{Bcl} 2$ was only observed in the heterotopic brain tissue of both groups E18 and P8 (Figure 2) with no statistical difference between them.

TABLE 1 - PCNA labeling index in fetal and neonatal control brain and in fetal and neonatal heterotopic brain tissue in the lung

\begin{tabular}{ccc}
\hline \multicolumn{1}{c}{ PCNA - LI (\%) } & p-value \\
\hline E18 (46\%) & P8 (18\%) & $\mathrm{p}<0.05$ \\
E18 (46\%) & CE18 SVZ (38\%) & n.s. \\
E18 (46\%) & CE18 Cortical (0.17\%) & $\mathrm{p}<0.05$ \\
E18 (46\%) & CE18 media (14\%) & $\mathrm{p}<0.05$ \\
P8 (18\%) & CP8 SVZ (19\%) & n.s. \\
P8 (18\%) & CP8 Cortical (0.12\%) & $\mathrm{p}<0.05$ \\
P8 (18\%) & CP8 media (11\%) & n.s. \\
CE18 SVZ (38\%) & CP8 SVZ (19\%) & $\mathrm{p}<0.05$ \\
CE18 Cortical (0.17\%) & CP8 Cortical (0.12\%) & $\mathrm{p}<0.05$ \\
CE18 media (14\%) & CP8 media (11\%) & n.s. \\
CE18 SVZ (38\%) & CE18 Cortical (0.17\%) & $\mathrm{p}<0.05$ \\
CP8 SVZ (19\%) & CP8 Cortical (0.12\%) & $\mathrm{p}<0.05$
\end{tabular}

LI, labeling index; PBI, pulmonary brain tissue implantation; E18, heterotopic brain tissue group on the 18th gestational day; P8, heterotopic brain tissue group on the 8th postnatal day; CE18, control group on the 18th gestational day; CP8, control group on the 8 th postnatal day; SVZ, subventricular zone; n.s., not significant. 


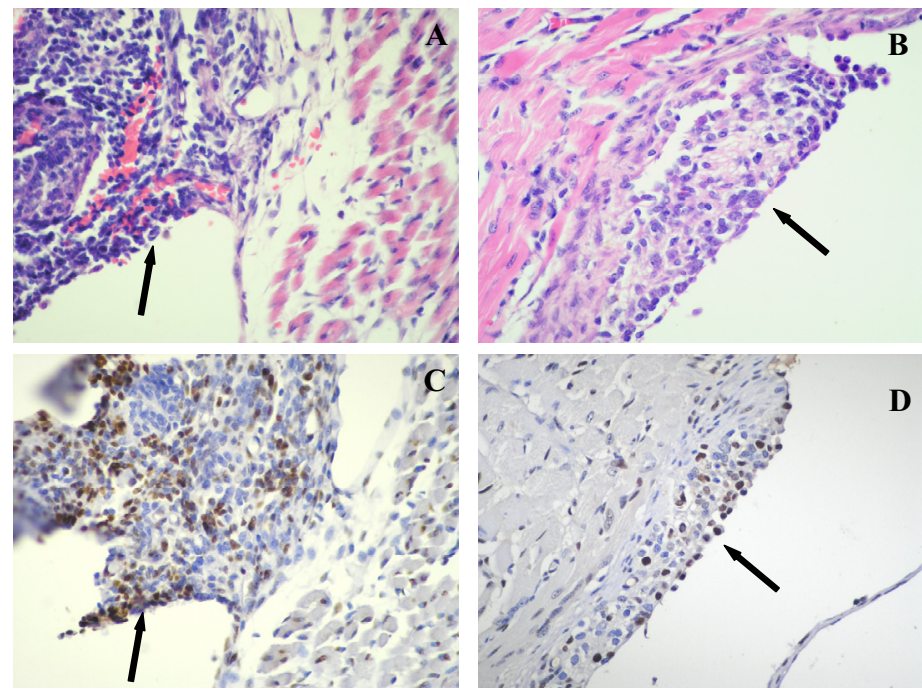

FIGURE 1 - Photomicrograph of histological sections of the fetal trunks with heterotopic brain tissue (arrows) stained with Hematoxylin and Eosin and submitted to immunohistochemical reaction with PCNA antibody. A and $\mathrm{C}$ are from $\mathrm{E} 18$ group, whereas $\mathrm{B}$ and $\mathrm{D}$ are from $\mathrm{P} 8$ group. Note the less intense immunostaining in P8 group when compared with E18 group, both with fragments implanted over the parietal pleura (arrows). (A e B: Hematoxylin and eosin staining; $\mathrm{C}$ and $\mathrm{D}$ : Immunohistochemical reaction using the $\mathrm{ABC}$ method with the primary PCNA antibody; developed with $\mathrm{DAB}, 400 \mathrm{X}$ original magnification)

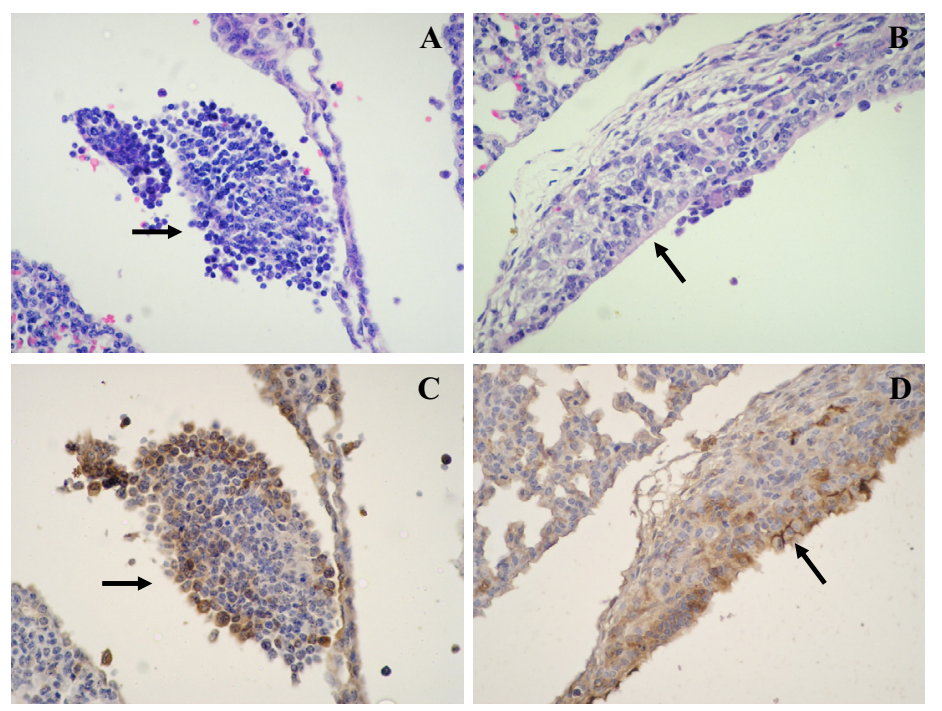

FIGURE 2 - Photomicrograph of histological sections of the fetal trunks with heterotopic brain tissue (arrows) stained with Hematoxylin and Eosin and submitted to immunohistochemical reaction with Bcl2 antibody. A and $\mathrm{C}$ are from $\mathrm{E} 18$ group, whereas $\mathrm{B}$ and $\mathrm{D}$ are from $\mathrm{P} 8$ group, both with fragments over the visceral pleura (arrow). (A and B: Hematoxylin and eosin staining; C and D: Immunohistochemical reaction using the SuperPicTure Polymer Detecetion Kit method with the primary Bcl2 antibody; developed with DAB, 400X original magnification)

\section{Discussion}

Proliferation and cell fate determination in the developing brain are regulated by intrinsic cellular programs and are extrinsically regulated by multiple interactions among a large number of secreted molecules, such as Sonic Hedgehog (SHH), epidermal growth factor (EGF), and fibroblast growth factors (FGFs) which usually act in a concentration-dependent manner ${ }^{14}$.
The concentration of these morphogens are modulated in turn by components of the extracellular matrix (ECM). However, little is known how lung ECM can influence proliferation and cell fate in heterotopic brain tissue.

Although the presence of heterotopic brain tissue in the lung is a rare condition ${ }^{10,11,15}$ the understanding of the biological phenomenon involved in implantation, interaction, proliferation, apoptosis and survival of the brain tissue in a place different from its origin is interesting. Most of the human cases are seen in fetuses or babies affected by open neural tube defects through inhalation of fragments of brain floating in the amniotic liquor, but it is also possible that a vascular route may operate. In fact, this is the mechanism for brain tissue embolism in violent head trauma such as car accidents and fall from height. In these cases, death supervenes immediately or shortly giving no time for the embolized tissue implant, but a recent concern has arisen in case of lung of multiple organ transplant using tissues from these patients. Therefore, the understanding of brain tissue heterotopia in the lung may prove useful.

In the present study, the fragments of brain tissues were well preserved and at times showed mitoses in cells positive for PCNA, indicating preserved proliferative ability of these cells in both fetal and neonatal periods. This result is in accordance with the findings in human cases reported by Kanbour et al. ${ }^{10}$ and Chen et al. ${ }^{11}$, who have identified a diffuse proliferation of the glial cells.

As expected, PCNA-labeled cells were more prominent in both experimental and control fetal groups than in neonatal ones, since cell proliferation is higher during the fetal period, although in the mouse brain development after birth is more prominent than in humans ${ }^{16}$. Due to the fact that the implanted brain tissue results from the disaggregation of the donor brain we do not know from what region it came and so comparison was done with the mean count obtained from cortical and SVZ. Analyzed separately, heterotopic brain tissue PCNA LI was higher than control brain for cortical region or the mean of cortical and SVZ, but not when compared to SVZ only, because the latter is the normal proliferative region. In view of these considerations, a stimulus for cell proliferation in heterotopic tissue is likely and deserves further investigation. The same did not happen in the neonatal period, in which the difference was observed only for cortical region, known to be the destination of already differentiated cells.

The mechanisms underlying reactive neural and glial proliferation are not yet fully understood, but the cell cycle control system seems to play an important role. In general, activation of a variety of proteins is involved in cell cycle progression during proliferation. Hypoxia and ischemia induces cell cycle activation that is associated with upregulation of the proliferating cell nuclear marker (PCNA) ${ }^{17}$ which may support the findings in the study, mainly the increase of immunostaining for PCNA antibody in E18 group. Additionally, hypoxia also activates quiescent neural progenitor cells that result in neurogenesis ${ }^{18}$.

The increase of heterotopic brain tissue cells immunostained with $\mathrm{Bcl} 2$ antibody in the experimental groups when compared with control ones may be explained by the extraction of the brain from the donor fetus, its mechanical disaggregation and eventual injection into the thorax of the receptor siblings, which is quite aggressive and potentially induces cell death. In addition, some aberrant cell cycle activation can lead to apoptosis in postmitotic cell, such as neurons ${ }^{17,19,20}$ Cell cycle proteins are normally 
down-regulated in post-mitotic neurons ${ }^{19}$ and re-entry into the cell cycle can cause apoptosis in such cells ${ }^{20}$. Up-regulation of cell cycle proteins is correlated with neuronal apoptosis after experimental spinal cord injury ${ }^{19}$ and brain injury ${ }^{21}$. Thus, whereas aberrant cell cycle activation causes apoptosis in postmitotic cells, it induces proliferation in mitotic cells such as astrocytes and microglia ${ }^{21}$.

These results can explain our previous findings of neuronal maturation with proportional reduction of the number of these cells compared to the controls using this mode ${ }^{13}$, indicating that there was a selective reduction in the neural population, maybe because immature and mature neurons are more likely to injury than glial cells ${ }^{18}$. A similar mechanism possibly occurs in human cases, since one explanation for its development is the disruption of the exposed brain tissue in neural tube defects resulting in aspiration of floating brain fragments in the amniotic fluid that eventually lodge in the lung $8,9,22$.

\section{Conclusion}

In the present study, the brain tissue was well preserved with cells positive for PCNA, indicating preserved proliferative ability of these cells in both fetal and neonatal periods, although apoptosis is also induced. Future studies aimed at the investigation of growth factors and cell cycle molecules using this model may help to further clarify the mechanisms of neural cell proliferation and death in heterotopic brain tissue in the lung.

\section{References}

1. Takahashi T, Nowakowski RS, Caviness VS Jr. Early ontogeny of the secondary proliferative population of the embryonic murine cerebral wall. J Neurosci. 1995;15:6058-8.

2. Oppenheim RW. Cell death during development of the nervous system. Annu Rev Neurosci. 1991;14:453-501.

3. Qian X, Shen Q, Goderie SK, He W, Capela A, Davis AA, Temple S. Timing of CNS cell generation: a programmed sequence of neuron and glial cell production from isolated murine cortical stem cells. Neuron. 2000;28:69-80.

4. Girós A, Morante J, Gil-Sanz C, Fairen A, Costell M. Perlecan controls neurogenesis in the developing telencephalon. BMC Dev Biol. 2007;5:7-29.
5. Raff MC. Social controls on cell survival and cell death. Nature. 1992;356:397-400.

6. Gordon N. Apoptosis (programmed cell death) and other reasons for elimination of neurons and axons. Brain Dev. 1995;17:73-7.

7. Mashayekhi F. Neural cell death is induced by neutralizing antibody to nerve growth factor: An in vivo study. Brain Dev. 2008;30:112-7.

8. Peres LC, Barbosa GHTS, Hansinginf SE, Pina-Neto JM. Heterotopic Brain tissue in the lung. Annals Diagn Paediatr Pathol. 2003;7:41-4.

9. Morgan T, Anderson J, Jorden M, Keller K, Robinson T, Hintz S. Pulmonary glial in a monoamniotic twin. Pediatr Pulmonol. 2003;36:162-6. 10. Kanbour AI, Barmada MA, Klionaky B, Mossy J. Anencephaly and heterotopic central nervous tissue in lungs. Arch Pathol Lab Med. 1979;103:116-8.

11. Chen WJ, Kelly MM, Shaw CM, Mottet NK. Pathogenic mechanisms of heterotopic neural tissue associated with anencephaly. Human Pathol. $1982 ; 13: 179-82$.

12. Quemelo PRV, Sbragia L, Peres LC. Development of an experimental model of brain tissue heterotopia in the lung. Int J Exp Pathol. 2007;88:337-42. 13. Quemelo PRV and Peres LC. Neuronal maturation in an experimental model of brain tissue heterotopia in the lung. Exp Biol Med. 2008;5:535-9. 14. Kohtz JD, Baker DP, Corte G, Fishell G. Regionalization within the mammalian telencephalon is mediated by changes in responsiveness to Sonic Hedgehog. Development. 1998;125:5079-89.

15. Peres LC, Barbosa GHTS. Brain tissue aspiration in neural tube defect. Arq Neuropsiquiatr. 2005;63:614-7.

16. Alvarez-Buylla A, Garcia-Verdugo JM. Neurogenesis in adult subventricular zone. J Neurosci. 2002;22:629-34.

17. Zhu Z, Zhang Q, Yu Z, Zhang L, Tian D, Zhu S, Bu B, Xie M, Wang $\mathrm{W}$. Inhibiting cell cycle progression reduces reactive astrogliosis initiated by scratch injury in vitro and by cerebral ischemia in vivo. Glia. 2007;55:546-58.

18. Zhou L, Miller CA. Mitogen-activated protein kinase signaling, oxygen sensors and hypoxic induction of neurogenesis. Neurodegener Dis. 2006;3:50-5.

19. Byrnes KR, Stoica BA, Fricke S, Di Giovanni S, Faden AI. Cell cycle activation contributes to post-mitotic cell death and secondary damage after spinal cord injury. Brain. 2007;130:2977-92.

20. Becker EB, Bonni A. Cell cycle regulation of neuronal apoptosis in development and disease. Prog Neurobiol. 2004;72:1-25.

21. Byrnes KR, Faden AI. Role of cell cycle proteins in CNS injury. Neurochem Res. 2007;32:1799-1807.

22. Mendonça ED, Gutierrez CM, Peres LC. Brain tissue fragments in the amniotic fluid of rats with neural tube defect. Pathology. 2005;37:152-6.

\section{Correspondence:}

Conflict of interest: none

Paulo Roberto Veiga Quemelo

Universidade de Franca

Depto Ortopedia e Traumatologia

Av. Armando Salles de Oliveira, 201

14404-600 Franca - SP Brazil

Phone: (55 16)3711-8720

pquemelo@hotmail.com

Received: January 12, 2010

Review: March 17, 2010

Accepted: April 14, 2010

\section{How to cite this article}

Quemelo PRV, Peres LC. Proliferation and cell death in an experimental model of brain tissue heterotopia in the lung. Acta Cir Bras. [serial on the Internet] 2010 July-Aug;25(4). Available from URL: http://www.scielo.br/acb 